\title{
HEGEL'S AESTHETICS AND SOVIET MARXISM: MIKHAIL LIFSHITS'S COMMUNIST IDEAL
}

Angela Harutyunyan

American University of Beirut

Ah140@aub.edu.lb
A B S T R A C T

This paper discusses the materialist reading of Hegel's Aesthetics by Soviet philosopher Mikhail Lifshits in his writings in the 1930s. Engaged in the development of Soviet Marxian aesthetic theory, Lifshits adapted the Hegelian conception of art as a form of truth and actualisation of the Idea in a sensible form as ideal. However, he rejected Hegel's tragic fatalism regarding the historical fate of arts and their sublation in a new supra-sensual stage of the Spirit's development. Lifshits sought the only answer to the historical destiny of arts in the Marxian dialectic of history. Here, he identified the aesthetic ideal with the realisation of communism. It is on this basis that throughout the 1930s Soviet aesthetic theory combined readings of Hegel, Marx, Engels and Lenin in order to develop its own version of art's autonomy, one that was anchored in the concept of the ideal. The ideal in its historical and trans-historical dimension was seen as bridging between sensuousness and truth, and pointing towards the communist ideal. The paper argues that this concept of the ideal pointed towards a dialectical futurity that could not succumb to the official Stalinist formulations of dialectical materialism. Unlike the Stalinist victory of "socialism in one country" as the consummation of the historical dialectic, the question of the historical destiny of arts pointed at communism as an incomplete and yet historically actualisable ideal.

KEY WORDS

HEGEL

MARX

AESTHETICS

DIALECTICAL MATERIALISM

IDEAL

SENSUOUSNESS

HISTORICAL DESTINY OF ARTS 
The Soviet dialectical materialism's relationship with Hegel is a complex and even a thorny one. While dialectical materialism was politically implemented in the 1930s as 'the world outlook of the Marxist-Leninist party', Hegel was expelled from Stalinist orthodoxy. Yet, at the very height of Stalinism in 1937, the Soviet Academy of Sciences published Hegel's Science of Logic in the fifth volume of Hegel's Works followed by the first and second volumes of Hegel's Aesthetic: Lectures in Fine Art in 1938 and 1940 respectively. ${ }^{1}$ Within the official Diamat (hereafter referred to as Diamat when implying its Stalinist interpretation) that synthesises Marx, Engels and Lenin, and largely relies on Engels's Dialectic of Nature, Hegel is an absent-present ghost, expelled from the pantheon of references and yet silently formative for this very pantheon. Yet, as opposed to orthodox philosophy proper, the Soviet Marxian aesthetic theory largely relies on the explicitly Hegelian concept of art as a form of truth and actualisation of the Idea in a sensible form as ideal. However, as opposed to Hegel, it identifies this ideal with the realisation of communism. It is on this basis that throughout the 1930s Soviet aesthetic theory combines readings of Hegel, Marx, Engels and Lenin in order to develop its own version of art's autonomy, one that was anchored in the concept of the ideal. The ideal in its historical and trans-historical dimension was seen as bridging between sensuousness and truth, and pointing towards the communist ideal. It is this concept of the ideal that, I argue, pointed towards a dialectical futurity that could not succumb to the official Stalinist formulations of dialectical materialism. Rather than a broad survey of how Hegel was received in the Soviet aesthetic theory in the 1930s, this paper focuses on the writings of Mikhail Lifshits, one of the key figures in the development of the Soviet Marxist art historical method and aesthetic theory. After outlining the main tenets of dialectical materialism in its Stalinist formulation in the late 1930s, the paper turns to Lifshits's attempts at combining Hegel's aesthetics with Marx's and Engels's dialectic of history to address the central question of the historical destiny of arts. Unlike the Stalinist victory of "socialism in one country" as the consummation of the historical dialectic, the question of the historical destiny of arts points to communism as an incomplete and yet historically actualisable ideal.

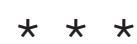

It is noteworthy that the orthodox Stalinist formulation of dialectical materialism in its utmost official form appears in a textbook. This is not a regular textbook but one that was to cement the Stalinist version of the history of the Bolshevik Party after the physical annihilation of the fellow Bolsheviks. But the Party's history would only be partial if it were not justified philosophically on the basis 
of dialectical materialism. The notorious The Short Course of the History of the All-Russian Communist Party (Bolsheviks) [Kratkii kurs istorii VKP(b)] (herein referred to as The Short Course) appeared in 1938, with the initial print of six million copies (reaching more than 40 million copies until Stalin's death) and was translated to 67 languages during Stalin's life. He allegedly could not entrust historians and philosophers to write the chapter on Dialectical Materialism, even if those who had gone through a period of "re-education" in the 1930s, after which they were allowed to write the historical chapters. It is widely believed that Stalin himself wrote the part on Dialectical Materialism. The chapter starts with a formulation that would become common place up until the collapse of the USSR:

'Dialectical Materialism is the world outlook of the Marxist-Leninist party. It is called dialectical materialism because its approach to the phenomena of nature, its method of studying and apprehending them, is dialectical, while its interpretation of the phenomena of nature, its conception of these phenomena, its theory, is materialistic. Historical materialism is the extension of the principles of dialectical materialism to the study of social life, an application of the principles of dialectical materialism to the phenomena of the life of society, to the study of society and its history'. ${ }^{2}$

According to this formulation of dialectical materialism grounded in Engels's Dialectic of Nature (1883), which itself borrows from Hegel's laws of the dialectic, the latter is based on three fundamental laws that cover both nature and history, matter and consciousness: the law of the transformation of quantity into quality and vice versa; the law of the interpenetration of opposites and the law of the negation of negation. The transformation from quantity to quality is the essence of motion and brings about history through differentiation. In Engels's formulation, history at its capitalist stage is still too close to the animal kingdom because the social organisation of production among mankind is not consciously planned to serve mankind equally. It is with communism that the Dialectic of Nature turned to the Dialectic of History, achieves its highest qualitative state with the conscious organisation of social production. Hence, communism is staged as the highest and most rational organisation of social life and one that synthesises all historical development in the highest form. ${ }^{3}$

Stalin's article follows Engels's formulation and embodies his customary method of collaging the necessary quotes from Marx, Engels and Lenin to advance his argument. Applied as a schema, Stalin's Diamat is based on the crude and 
undialectical distinction between matter and consciousness, wherein matter is viewed as primary and the mind and thought as derivative of it. In granting matter ontological primacy over thought, this textbook, as Soviet philosopher and logician Bonifaty Mikhailovich Kedrov commented in the 1960s, excluded thought from philosophy altogether, and so the Leninist identity of dialectic, logic and theory of knowledge was undone. ${ }^{4}$

Stalin-the-theoretician's most notable 'innovation' in the redefinition of Diamat (and this is what allows us to ultimately make a distinction between dialectical materialism and its Stalinist variant - Diamat) is his tacit and sneaky omission of the final law of the dialectic, the negation of negation, which is the precondition for revolutions conceived as ruptural events. In the Stalinist Diamat, history is overdetermined by laws of nature, while revolutions appear as evolutions. 'Further, if the passing of slow quantitative changes into rapid and abrupt qualitative changes is a law of development, then it is clear that revolutions made by oppressed classes are a quite natural and inevitable phenomenon. ${ }^{5}$ It is this naturalness and inevitability of historical events, including the revolutions that provide the ultimate justification of the Stalinist Soviet state as a historical-transhistorical formation. Stalinism combines revolutionary and accelerated methods in economy as exemplified in the command-controlcoercion logic of the Five-Year Plans (the first one taking place during Stalin's so-called Great Break in 1928-32) with "gradualism" in political theory and historical development. Revolutions are not conceived as determinate negations of the social order but inevitable events inscribed in the evolutionary logic of historical development, and one could add, orchestrated from the top, as in Stalin's second revolution of 1928.

The Stalinist Diamat as philosophy and science at once, a science materialised as a particular social formation in state socialism declared as triumphant in the 1936 Soviet Constitution, reaches its final fulfillment in the Party of the proletariat as a permanent historical-transhistorical formation. The paradox is as follows: while rhetorically insisting on the interpenetration of the opposites and thus also on contradictions, on the law of unceasing movement and negation, Diamat as Stalinist orthodoxy freezes all further historical development and territorialises movement within the extant Soviet state. Read dialectically, we could say that in this conception, once History has been fulfilled in Stalin's statist formation it accomplishes a full circle and rejoins Nature. History appears as natural history. What is forsaken here is the realisation of communism as a historical ideal and as an actual possibility. 
I argue that Lifshits's aesthetic theory based on Hegel's aesthetics and Marx's materialist conception of history, preserved the historical futurity of the aesthetic ideal in its identification with the communist ideal. But it did so from within dialectical materialism and contrary to Diamat. Thus, it formed an opposition to Stalinism within Stalinism itself. For Lifshits, the key to identifying communism and the aesthetic ideal was the question of the historical destiny of arts that could be solved only within a Marxian framework, hence his project of reading Hegel materialistically, in the footsteps of Marx and Lenin.

For Lifshits, the translation of Hegel's idealist aesthetics to the language of his contemporary materialism was not only a political imperative but it was also a key for developing a systematic aesthetic theory based on Marx. Rather than abstracting a theory of art and aesthetics from the writings of Marx where the latter didn't develop one systematically, Lifshits would point to the aesthetic dimension of Marx's thought from his early endeavors as editor of Rheinischer Zeitung in the early 1840 s to his mature works - A Contribution to Critique of Political Economy (1859) and Capital (1967-1894). ${ }^{6}$ Throughout the commonplace battles against so-called vulgar sociologism, which both Lifshits and György Lukács spearheaded at the Marx-Engels Institute in Moscow in the 1930s, not only Marx but also Hegel's aesthetic theory came to provide ground for arguing for non-synchronicity between the material conditions and the products of the ideal: art and literature. Economy does not condition culture, but the former determines the latter in the last instance. There can be periods, such as in Ancient Greece, that the works of the spirit while determined by the level of the material development of Greek society produce ideals that are actual today. And the contradiction between lower stages of economic development and higher forms of artistic production are intrinsic to the very dialectic of history. There are objective material conditions that constrain the development of thought, but there is thought that breaks away from the constraints of those conditions. It is precisely for this very same reason that Hegel could not have come up with the conception of class antagonism as the driving force for historical development, and Marx could not occupy himself with purely aesthetic concerns. If Hegel's historical limitations were framed by the dominant bourgeois ideals of his time, Marx preoccupied himself with the social totality rather than with its individual spheres. For this reason, Marx could not develop a philosophy of art and aesthetics. And yet, the Hegelian conception of the ideal as the material actualisation of the idea combined with the Marxian materialist understanding of the development of history towards the communist ideal can provide an answer to the historical destiny of arts. This identification would make it possible to exit the historical cul-de-sac of the 
Hegelian 'end of art' on the one hand, and on the other provide an alternative to the mechanistic and vulgar causality between economic and social conditions and cultural production.

Lifshits' systematic reading of Hegel's Aesthetics throughout the 1930s precedes its first Russian publication in 1938. In the 1931 article entitled "Hegel's Aesthetics and Dialectical Materialism", Lifshits argues that Hegel could not have taken his dialectical conception of history as a development through contradiction to the end: these contradictions would historically crystalise only in the class contradictions between the bourgeoisie and the proletariat that became manifest in the aftermath of the 1830 July revolution. ${ }^{7}$ Lifshits finds the limitations of Hegel's thought not only in Hegel's historical circumstances but also in his historical logic. According to the latter, the law of the negation of negation as a higher logical form of affirmation is not a revolutionary one but is politically translated to the stability of the rule of the bourgeoisie with the Prussian state serving as the ultimate habrour of the Spirit. Reconciliation of antagonisms in a higher logical and historical form in Hegel functions as 'a magical word for gluing together' the fragmented world torn asunder by revolutionary violence and destruction. If in young Hegel the ideal of Greek democracy as the highest political form is connected to the renaissance of the culture of Greek Antiquity, in later works dealing with the ongoing tide of capitalist transformations, for Hegel neither history nor the arts can go back to some initial stage. Lifshits states:

'And it is not his fault that the extent historically conditioned form of progress had thus far always violently oppressed popular initiative and imagination cutting off, almost without any residue, the rich aesthetic culture springing from popular soil. But he leaves aside the historically transient character of this process'. ${ }^{8}$

Lifshits's major disagreement with Hegel is the Hegelian solution to the destiny of arts as their annihilation through historical progress. ${ }^{9}$ Hegel's historical end of art ultimately takes place through the sublation of sensuous actualisation. But for Lifshits, the death of art is a resignation to bourgeois asceticism: the bourgeoisie with its calculative reason, means-to-an-end-rationality first punishes the aristocracy for sensuous enjoyment, and then deprives the masses of it as well. Instead of advocating plebeian denial of aesthetic pleasure or conceptual aloofness from enjoyment, he insists on the inherently democratic character of aesthetics grounded in non-sublatable sensuousness. In Marx and Engels on Art, Lifshits states: 
'Art cannot exist without a sensual basis; the idea of the artist demands an objective embodied form. This is the law of the sphere of aesthetics that has an irreplaceable meaning for human society. In its foundation lies the ideal of life that has developed from the entire history of mankind, one that is purified from crude materiality but is nevertheless real. The inevitable domination of the abstract culture of the spirit cut off from the physical labor of the majority of people in a class society is hostile to it. Historically the world of art and poetry is firmly connected to the popular roots of social life, and its presence in this life is a symbol of true democracy, more or less clearly understood ${ }^{10}$

Art as a form of unsurpassable and non-sublatable sensuousness in its most radically democratic and popular realisation is identical with communism as the social formation where the sublation of alienation can be achieved. If, from a materialist perspective, aesthetic sensibility arises from the development of the faculties through the foundational activity of labour, while ideation is an imprint of historically constituted productive activity, the liberation of labour from its enslavement to exchange value and the liberation of aesthetic sensibilities from the partiality of class-belonging can't be disentangled. As the human moves further away from the world of need, his or her occupation with the form and structure of the object becomes autonomous from the utility and function of the object, and thus, the aesthetic sensibility as an autonomous domain from the world of need is constituted. But the autonomy of aesthetics is truly achieved when the human is truly free from production, and when there is no longer a division between freedom and necessity. This is when the historical right of the masses to sensuous self-realization is achieved.

Throughout the 1930s and even thereafter in the 1960s and 1970s, when the prospects of communism were becoming increasingly distant, Lifshits always spoke from the perspective of the victory of socialism, and upheld what can be called tragic optimism, the increasingly difficult belief in the realisation of communism as the overcoming of alienation. The artistic appropriation of the objective world is one of the central means of the appropriation of the world through a man's sensuous productive activity, according to the laws of beauty and criterion of truth. But as opposed to the crude and direct form of the appropriation of the object, on the basis of artistic activity is a universal measure (which for Lifshits, is often identical with the ideal). In the capitalist division of labour the masses succumb to the world of need and crude materiality. There the gap between rote labour and creativity is unsurpassable. In contrast, communism bridges the gap between labour and creative play and thus provides a historical 
answer to the problem of alienation. From this perspective, any post-Hegelian declaration of the end of art is inevitably replete with bourgeois resignation and nihilism. For Lifshits, it is only the Marxian conception of history that is capable of providing an answer to the question of the historical fate of arts.

The specificity of Lifshits's philosophy of art and much of the Soviet Marxist aesthetics and art theory (including Lukács as someone who bridges Soviet and Western Marxism) is that while the historical dialectic of emancipation is oriented towards the future, the works of art and literature that best capture the ideal are located in the past. ${ }^{11}$ The ideal as the historical-transhistorical objective measure is that which orients consciousness toward truth, goodness, beauty and justice. For Lifshits, who is largely responsible for the construction of the field of Soviet Antiquity studies, ${ }^{12}$ the ideal was conceived as actualised in the art of the past, and specifically in Greek Classical art. Here, to be socialist meant to uphold classicism as the highest aesthetic ideal and conceive of Socialist Realism as a return to classicism in drastically transformed and progressive historical conditions. Socialist Realism, in short, was seen as the re-enactment of Classical Antiquity on a higher historical plane under which political avantgardism was established through an anti-avant-garde consciousness.

While Lifshits upheld the Hegelian conception of art as a mode of truth, he never opposed truth to sensuousness, and while reading Hegel materialistically, he didn't dilute Hegel's objective idealism into dialectical materialism. In the 1931 article mentioned above, he states:

'Hegel's philosophy and dialectical materialism themselves express two opposing historical paths, two types of material and spiritual development. By creating deep roots for the initiative of the masses, realizing free collaboration between nations and destroying civilizational limitations the same way as capitalism destroyed patriarchal limitations, socialist society is heading towards eliminating those causes that prompted the best representatives of thinking mankind to find consolation in the idea of tragic fate'. ${ }^{13}$

The Hegelian movement of the Spirit as a struggle against itself on the thorny road of development is historically tragic from the point of view of Lifshits's historical optimism. The dialectic in Hegel appears in its idealistic form as a permanent development similar to the permanent and unlimited development of production for production's sake in capitalism in the writings of bourgeois political economists. Lifshits is unwilling to accept the tragic cost that development suffers in the Hegelian system: all good has to die out, and 
development comes through negation, violence, wiping out entire nations and people, by crushing individuality and so on. In Hegel, one has to reconcile with this fate brought about by the triumphant march of the Spirit. As opposed to this logic of reconciliation, Marx discovered the proletariat as a solution to his philosophical system: here antagonisms cannot be reconciled in the ideal state but they appear in their sharpest contours in the practical revolutionary struggle for communism. And it is here that the historical destiny of arts cannot be disentangled from the historical resolution of class antagonisms in communism.

Lifshits reads Hegel's Aesthetics as closest to Marx's materialism since the former is the meeting point of the concept and the living forms of the concrete world, of freedom and necessity despite the violence of Aufhebung. The historical possibility for the actualisation of art as a mode of truth and the universal development of the human senses of beauty and goodness, as I have argued, positions Lifshits's Marxian philosophy of art and aesthetics of the 1930s informed by Hegel's aesthetics as an internal opposition to the official Stalinist Diamat. The latter establishes the Soviet state as the final historical realisation of the dialectical movement of matter, while relegating communism to an unrealisable utopian horizon. In this context, it is through a dialectically materialist reading of Hegel that Lifshits upholds communism as an actual historical possibility. Here communism is identical with the aesthetic ideal as the ideal of de-alienation. He incessantly upheld this historical optimism to the very end of his life. In his 1984 response to Eval'd Ilyenkov's On the Concept of the Ideal after Ilyenkov's tragic suicide, Lifshits still sees the inevitable historical road of de-alienation as a movement through which the real strives towards identity with its concept, and becomes a condition for truth. For instance, society is made identical with its concept with the arrival of the communist society, and until then the truth that communism embodies the ideal haunts society that has yet to become identical with its concept. In Lifshits's positive dialectic there is a movement toward higher forms of truth, good and beauty embedded in the purposefulness of nature that extends from nature to the social world. And it is this movement of reality towards consciousness that brings about the capacity to pierce through the reign of commodity fetishism. For Lifshits:

'The drama of contemporary civilization clearly demonstrates that alienated "representations" and "stereotypes" can crush all ideality the ideals of reason, of good and beauty,- if reality itself indifferent in its natural or social material being, does not meet hallway the social thought enclosed within these ideals. And it's a good thing when reality destroys what is ready-made in culture, and when what Engels called the "triumph of realism" is accomplished'. ${ }^{14}$ 
Lifshits's insistence on the primacy of objective reality and the inevitable historical accomplishment of communism today may sound like an echo from another world, especially since that world has seemingly vacated the stage of history. And yet, perhaps his aesthetics with its future-directed historical trajectory is still capable of providing an alternative to the ongoing and manifold 'ends of art', and perhaps the funeral has always been for the wrong corpse. ${ }^{15}$ 
Hegel, Sochinenie, V 14-ykh tomakh, vol. 5, Nauka Logiki, trans. B.G. Stolpner, (Gosudarstvenno social'no-ekonomicheskoe izdatel'stvo "Poligrafkniga": Moscow, 1937) and vol. 12-13, Lekstii po Estetike, trans. B. G. Stolper, ibid. The third volume is published only in 1958 with P. S. Popova's translation as the final and fourteenth volume of Hegel's Works.

The Short Course of the History of the All-Russian Communist Party (Bolsheviks). (International Publishers, New York: 1939), 105.

If in the USSR historical materialism as a scientific method of understanding society historically was conceived as part and parcel of the dialectic of nature, Western Marxism rejected this dialectic of nature by relying on the assumption that Nature cannot be dialectical because it has no negativity within itself, and is indifferent to us, humans and thus extra-historical.

B. M. Kedrov, Edinstvo dialektiki, logiki i teorii poznaniia, Moscow, 1963, 12, 117, 119. Quoted in James P. Scanlan, Marxism in the USSR: A Critical Survey of Current Soviet Thought (Cornell University Press, 1985), 160

M. Lifshits, Karl Marx i vopros ob istoricheskix sudbax iskusstva, Krasnaya nov', 1933. N. 3, 176190; Philosophia iskusstva Karla Marksa, Moscow, 1933. The latter book is the first translation of Lifshits's work in English: The Philosophy of Art of Karl Marx. Ed. by Angel Fores (New York: Critics Group), 1938.

Originally published in M. Lifshits, "Estetika Gegelya i dialekticheskiy materialism”, Proletarskaya literatura, Moskva, 1931, no. 5-6, 76-93. In M. Lifshits, O Gegelye (Grundrisse: Moscow, 2012), Ibid., 74.

Ibid. See also The Philosophy of Art of Karl Marx.

M. Lifshits, Philosophia iskusstva Karla Marksa, in Sobranie socheneniy v trekh tomax, vol. 1 (Izobrazitel'noe iskusskto: Moscow, 1984), 138-139. In Russian, trans. Angela Harutyunyan.

However, in the 1940s both Lifshits and Lukács came out with strong justifications for Socialist Realism as a higher form of the development of the ideal.

12 Vardan Azatyan, Art History of Idea and its Troubles: Humanism, the Cold War, and a Soviet Periphery. Unpublished draft manuscript.

M. Lifshits, $O$ Gegele, ibid., 94.

Mikhail Lifshitz, Dialog s Eval'dom Il'yenkovim (Problema ideal'nogo) (Moscow: Progress Traditsiaya, 2003), 275.

Hal Foster, "This Funeral is for the Wrong Corpse", Design and Crime (New York, London: Verso, 2002), 123. 
Azatyan, Vardan. Art History of Idea and its Troubles: Humanism, the Cold War, and a Soviet Periphery, unpublished draft manuscript.

Foster, Hal. "This Funeral is for the Wrong Corpse." In Design and Crime. New York, London: Verso, 2002.

Hegel, Georg Wilhelm Friedrich. Sochinenie, V 14-ykh tomakh, vol. 5, Nauka Logiki, trans. B.G. Stolpner, Gosudarstvenno social'no-ekonomicheskoe izdatel'stvo "Poligrafkniga": Moscow, 1937.

Lifshits, Mikhail. Karl Marx i vopros ob istoricheskix sudbax iskusstva, Krasnaya nov', 1933. N. 3, 176-190.

Lifshits, Mikhail. Philosophia iskusstva Karla Marksa, Moscow, 1933.

Lifshits, Mikhail. The Philosophy of Art of Karl Marx. Ed. by Angel Fores, New York: Critics Group, 1938.

Lifshits, Mikhail. O Gegelye, Grundrisse: Moscow, 2012.

Lifshits, Mikhail. Dialog s Eval'dom Il'yenkovim (Problema ideal'nogo), Moscow: Progress Traditsiaya, 2003.

James, P. Scanlan. Marxism in the USSR: A Critical Survey of Current Soviet Thought. Cornell University Press, 1985.

The Short Course of the History of the All-Russian Communist Party (Bolsheviks). International Publishers, New York: 1939. 
HEGELOVA ESTETIKA I SVETSKI MARKSIZAM: KOMUNISTIČKI IDEAL MIKHAILA LIFŠITSA

\section{Angela Harutyunyan}

Ovaj rad se bavi materijalističkim čitanjem Hegelove Estetike od strane sovjetskog filozofa Mihaila Lifšitsa (Mikhail Lifshits) iz njegovih spisa iz 1930-ih. Radeći na razvoju sovjetske marksističke teorije estetike, Lifšhits je prilagodio hegelovski koncept umetnosti kao vrste istine i aktualizacije Ideje u razumnom obliku kao idealnom. Medjutim, on je odbacio Hegelov tragični fatalizam u vezi sa istorijskom sudbinom umetnosti i njihovu podredjenost u novoj supra-čulnoj fazi razvoja Duha. Lifšits je tražio jedini odgovor na istorijsku sudbinu umetnosti u marksističkoj dijalektici istorije. Tu je identifikovao estetski ideal sa realizacijom komunizma. Na toj osnovi, tokom 1930-ih sovjetska teorija estetike kombinovala je čitanja Hegela, Marksa, Engelsa i Lenjina kako bi razvila sopstvenu verziju autonomije umetnosti, onu koja je utemeljena u konceptu ideala. Ideal je u svojoj istorijskoj i transistorijskoj dimenziji vidjen kao premošćivanje čulnosti i istine i usmeren prema komunističkom idealu. U radu se tvrdi da je ovaj koncept ideala ukazivao na dijalektičku budućnost koja nije mogla da podlegne zvaničnim staljinističkim formulacijama dijalektičkog materijalizma. Za razliku od staljinističke pobede „socijalizma u jednoj zemlji“ kao konzumacije istorijske dijalektike, pitanje istorijske sudbine umetnosti ukazalo je na komunizam kao nepotpun, a istorijski ostvariv ideal.

KLJUČNE REČI: HEGEL, MARKS, ESTETIKA, DIJALEKTIČKI MATERIJALIZAM, IDEAL, ČULNOST, ISTORIJSKA SUDBINA UMETNOST

\section{ODLOŽENA REAKCIJA NA HOMOFONSKU UZVIŠENOST: KOMEDIJA, PRISVAJANJE I ZVUKOVI JEDNE RUKE KOJA APLAUDIRA}

\section{Charles Bernstein}

Homofonski prevodi stvaraju pesme koje više ističu zvuk originala nego leksičko značenje. Započinjem raspravom o konceptu „Zvučnog pisanja“, pozivajući se na koncept „transkacije“ Harolda de Kamposa, Paundovu „transdukciju“ i koncept koji stoji iza kalka. Zatim razmatram svoje homofonske prevode finskog pesnika Levi Lehta (Leevi Lehto) i izofonski prevod Ulisesa Kariona (Ulises Carrión). Nakon ukazivanja na ideju Bazila Buntinga (Basil Bunting) da se značenje prenosi više zvukom neko leksičkim sadržajem, razmatram Hlebnikov (Khelbnikov) pristup zaumu (trans-značenje) i dela koja slično zvuče na osnovu pesme ptica ili zvukova životinja. U eseju se onda navodi nekoliko konkretnih primera: homofonski prevod Homera od strane Dejvida Melnika, prevod Magnetskih polja od strane Pjera Jorisa na osnovu prepoznavanja glasa i Džin Donelina verzija Ponža. Esej se završava diskusijom o knjizi Drift autorke Kerolin Bergval, njenoj verziji „The Seafarer", kao i njenim trans-kreacijama Čosera. U centralnom delu eseja se govori o „homofonskom“ prevodu u popularnoj kulturi, posebno „odloženoj reakciji“ Sida Cezara, najpopularnijeg TV komičara ranih 1950-ih. Diskusija o njegovom radu u kontekstu američke jevrejske komedije centralna je tema izlaganja. Ali drugi noviji popularni primer homofonije se obrađuje s posebnim osvrtom na kulturno prisvajanje.

KLJUČNE REČI: POEZIJA 20. VEKA, POETIKA, PREVOD, HOMOFONIJA, SID CEZAR, LUIS ZUKOFSKI, EZRA PAUND, KEROLIN BERGVAL, DEJVID MELNIK, JIDIŠ, ESPERANTO, PRISVAJANJE 